\title{
An analysis of risk factors for arterial hypertension in adolescent students
}

\author{
Jonathan Veloso Costa ${ }^{1}$ \\ Ana Roberta Vilarouca da Silva ${ }^{2}$ \\ Ionara Holanda de Moura ${ }^{3}$ \\ Rumão Batista Nunes de Carvalho ${ }^{4}$ \\ Lais Evêncio Bernardes ${ }^{5}$ \\ Paulo César de Almeida ${ }^{6}$
}

The objective of the study was to evaluate some risk factors for increases in systemic arterial blood pressure. This transversal study was carried out with 145 individuals from 12 to18 years of age at two state schools in the city of Pico in the state of Piauí in Brazil. The majority were female $(62.8 \%)$. The median age was 14.8 years $( \pm 3.19)$. It was ascertained that 13 of the subjects $(9.0 \%)$ were overweight [CI\% 73.0-86.0]. Elevations in waist circumference were found in 31 (21.4\%) and 76 (52.4\%) had elevated arterial blood levels. There was no statistically-significant association between the above-cited risk factors and gender $(p=0.088 ; 0.999 ; 0.204$, respectively). However, $44.8 \%$ of the adolescents had at least one risk factor associated with arterial hypertension; $15.9 \%$ had two, and $2.1 \%$ had three. The study confirms the influence of the risk factors on arterial pressure values among adolescents. Being aware of these factors means that nurses can intervene with health education measures.

Descriptors: Hypertension; Adolescents; Risk Factors.

\footnotetext{
${ }^{1}$ Undergraduate student, Universidade Federal do Piauí, Brazil. Scholarship holder from PIBIC-UFPI.

2 PhD, Adjunct Professor, Universidade Federal do Piauí, Brazil.

3 Undergraduate student, Universidade Federal do Piauí, Brazil. Scholarship holder from ICV-UFPI.

${ }^{4}$ Undergraduate student, Universidade Federal do Piauí, Brazil. Scholarship holder from UFPI.

${ }^{5}$ Undergraduate student, Universidade Federal do Piauí, Brazil. Scholarship holder from PIBIC-CNPq.

${ }^{6}$ PhD, Adjunct Professor, Universidade Estadual do Ceará, Brazil.
}

Corresponding Author:

Ana Roberta Vilarouca da Silva

Travessa Santo Antônio, 3126, Apto. 207

Bairro: Junco

CEP: 64600-000, Picos, PI, Brasi

E-mail: robertavilarouca@yahoo.com.br 


\section{Análise de fatores de risco para hipertensão arterial em adolescentes escolares}

O objetivo do estudo foi avaliar alguns fatores de risco para aumento dos níveis de pressão arterial sistêmica. Trata-se de estudo transversal, desenvolvido com 145 indivíduos de 12 a 18 anos, de duas escolas públicas da cidade de Picos, PI. A maioria era composta por mulheres $(62,8 \%)$. A média de idade foi de 14,8 anos $( \pm 3,19)$. Verificou-se que 13 $(9,0 \%)$ apresentavam excesso de peso [IC\% 73,0-86,0]. Elevações da circunferência abdominal foram encontradas em 31 (21,4\%), e $76(52,4 \%)$ tinham elevação nos níveis de pressão arterial. Não houve associação estatisticamente significante dos fatores de risco investigados citados anteriormente com o sexo ( $p=0,088 ; 0,999$; 0,204 , respectivamente). No entanto, $44,8 \%$ dos adolescentes tinham pelo menos um fator, $15,9 \%$ dois e $2,1 \%$, três fatores associados indicativos de hipertensão arterial. Confirma-se a influência de fatores de risco sobre os valores da pressão arterial em adolescentes. Diante do conhecimento desses fatores, a enfermagem poderá intervir com medidas de educação em saúde.

Descritores: Hipertensão; Adolescentes; Fatores de Risco.

\section{Análisis de los factores de riesgo para hipertensión arterial en adolescentes escolares}

El objetivo fue evaluar de los algunos factores de riesgo para aumento de los niveles de presión arterial sistémica. Estudio transversal con 145 personas de 12 a 18 años de dos escuelas públicas de la ciudad de Picos-PI. La mayoría eran mujeres (62,8\%). La edad media fue de 14,8 años ( \pm 3.19$)$. Se encontró $13(9,0 \%)$ tenían exceso de peso [IC\% 73,0 a 86,0]. Elevaciones de la circunferencia de cintura se encontraron en 31 $(21,4 \%)$ y $76(52,4 \%)$ con niveles elevados de presión arterial. No hubo asociación estadísticamente significativa de los factores de riesgo mencionados anteriormente investigado con el sexo ( $p=0,088,0,999,0,204$, respectivamente). Sin embargo, $44,8 \%$ de los jóvenes tenían al menos un factor; $15,9 \%$ dos y $2,1 \%$ tres factores relacionados con la hipertensión. Confirma la influencia de factores de riesgo en los valores de presión arterial en la juventud. Delante del conocimiento de estos factores, la enfermería podrá intervenir con medidas de educación en salud.

Descriptores: Hipertensión; Adolescentes; Factores de Riesgo.

\section{Introduction}

It is possible to observe that the Brazilian population is currently passing through a stage of epidemiological transition, there being an increase in the incidence of cases of diseases belonging to a group which has come to be known as chronic diseases. These are known for their prolonged nature ${ }^{(1-2)}$.

Chronic non-communicable diseases, of multifactorial cause, are responsible for thousands of deaths each year, with Systemic Arterial Hypertension (SAH) and Type 2 Diabetes Mellitus standing out. Both have risk factors in common and are associated with comorbidities, principally in the elderly, although they also affect adolescents and young adults.

$\mathrm{SAH}$, the subject of this study, is characterized by a decrease in blood vessel elasticity, which leads to an alteration in arterial pressure. In recent years, SAH has been increasingly considered one of the greatest challenges to public health, presenting an increased prevalency, above all in the young population. This is a worrying fact, as increased blood pressure levels in adolescence tend to remain so for life, bringing about precocious complications in adulthood. It should be 
emphasized that the risk factors investigated in this study, whether excess weight, waist circumference or blood pressure levels, are modifiable, meaning that the stage of adolescence should be the target for educative and preventive actions.

In Brazil, this chronic disease affects from $22 \%$ to $43.9 \%$ of the adult population, and $2 \%$ to $13 \%$ of the child and adolescent population ${ }^{(3)}$. In this context, it should be highlighted that the existence of arterial pressure alterations in children and adolescents provides evidence that hypertension can have its roots in this life stage, which should increase concerns about evaluation of arterial pressure in these groups ${ }^{(5-6)}$.

There are various factors involved in the development of hypertension over a lifespan: obesity, sedentarism, physical inactivity, and inappropriate eating habits, which are foremost among the principle factors which sensitize the organism to develop the disease(3).

The adolescents are directly exposed to the abovementioned risk factors, principally those concerning nutritional problems, such as excess weight or development of precocious obesity which precede SAH. The consequence of obesity in the juvenile population may become clear through the presence of some sequel in adulthood, with - apart from arterial hypertension dyslipidemias, insulin resistance, and type $2^{(7)}$ diabetes all standing out.

This being so, for epidemiological evaluation of arterial hypertensive syndrome, especially among children and adolescents, population-based studies must be developed, to permit the identification of the seriousness and scale of the disease, as well as the characterization of its risk factors ${ }^{(8)}$.

The directing of studies aimed at the young population may be justified by the fact that it could lead to less cardiovascular complications and consequent harm in the favourable condition of their lives, as the development of arterial hypertension in youth predisposes to a variety of cardiovascular complications in adulthood.

In this respect, knowledge concerning the prevalence of risk factors for chronic non-communicable diseases (CNCD) can alert students, educators and those in education management to the importance of the elaboration of prevention programs ${ }^{(4)}$. Specialists affirm that adolescents depend on their environment, consisting of their families and their peers, to obtain the conditions which result in the development of healthy living habits. Although there are individual factors which potentialize the development of $C N C D$, equally, the role of the family and of the environment can contribute, so as to avoid its development ${ }^{(9-11)}$.

Thus, the objective of this study was to evaluate excessive weight, waist circumference and elevated blood pressure levels as risk factors for $\mathrm{SAH}$ in adolescent students from two schools in Piauí.

\section{Methods}

This study is part of a research project titled 'Preventive Actions in the Control of Type 2 Diabetes Mellitus', with the subtitle 'Investigation of Risk Factors for Type 2 Diabetes Mellitus in Adolescents', carried out in two state schools in the city of Picos in the state of Piauí. Calculated with the use of the finite population formula, the sample was composed of 145 adolescents, aged between 12 and 18 years old, of both sexes, matriculated in the fifth to the ninth years of Junior School and from the 'Youth and Adults' accelerated education program. The schools were selected for their convenience, due to their being practice settings for the internships of the Piauí Federal University's Nursing course.

The study is descriptive and transversal. Three risk factors for arterial hypertension were evaluated: excess weight, elevated waist circumference and increases in the arterial blood pressure. Data collection was carried out between August and December 2010. The collection instrument utilized a formula with the following variables: age, sex, weight, height, body mass index (BMI), waist circumference (WC) and levels of arterial pressure (AP). As the project did not have financial backing, it was not possible to investigate the sample group's cholesterol and thus be able to use the Framingham Risk Score in order to evaluate the cardiovascular risk.

Simple random sampling was used for subject selection, by drawing lots among those who agreed to participate in the research and handed in the free and informed terms of consent, duly signed both by themselves and their parents or guardians. Students who affirmed they were undergoing treatment for SAH were excluded, along with those - such as people who were pregnant or in wheelchairs - who at the time of evaluation had some impediment to obtaining the anthropometric measurements.

The risk factors investigated will next be described: $A P, B M A$ and WC. For gauging AP, first of all a non-stretch tape measure was used for measuring the circumference of the adolescents' arms, at the mid-point between the olecranon and the acromion, with the ultimate aim 
of using this measurement to select the best-sized blood pressure cuff for each student. Arterial pressure was measured with an aneroid sphygmomanometer, checked immediately before use by INMETRO (the Brazilian National Institute for Meteorology, Quality and Technology), and with a cuff with the same width as the length of the rubber band closest to $40 \%$ of the circumference of the arm, used for attaching the cuff. As established, the correct measurement of arterial pressure in adolescents requires the use of a cuff appropriate to the size of the arm (mid-point between the olecranon and acromion). To comply with this recommendation, the equipment used for measuring AP included cuffs of different sizes, as well as a biauricular stethoscope and diaphragm for listening. Continuing as recommended, the cuff was placed $2 \mathrm{~cm}$ to $3 \mathrm{~cm}$ above the antecubital fossa. The diaphragm was free from clothing, the palm of the subject's hand was facing upwards, and the right arm was chosen so as to avoid false readings.

The checking of AP was carried out in a calm environment in each subject's own school, in a room reserved for this use on days arranged for data collection. The individuals were seated, with their feet on the ground, their legs uncrossed, the bladder emptied and the arm extended at the height of the fourth intercostals space, resting on a flat solid surface. Steps relating to relaxation were observed (from 5 to 10 minutes) ${ }^{(3)}$.

It is important to emphasize that three measuring of the arterial pressure were taken, with a one-minute interval between each, discarding the first and using the mean arterial pressure obtained from the last two. This step was taken to ensure the reliability of the control of data about arterial hypertension, with the aim of favouring its detection for possible continued observation of cases where alteration was found.

Concerning the classification of arterial blood pressure levels, after taking into account sex, age and stature percentiles, adolescents with systolic and diastolic pressure less than those corresponding to the ninetieth percentile were interpreted as normal. Those with systolic and/or diastolic levels greater than or equal to the ninetieth percentile and less than the ninety-fifth percentile, were termed 'pre-hypertensive'. Those who had systolic and diastolic pressure levels greater than or equal to the values corresponding to the ninety-fifth percentile ${ }^{(12)}$ were considered to have elevated arterial pressure, or supposed hypertensive. For those individuals over 17 years of age, the values were analyzed according to the recommendations of the Brazilian Society of Hypertension(13).
The data relevant to weight were obtained with the individuals without their shoes and wearing light clothes, using a set of portable digital scales able to weigh up to $120 \mathrm{~kg}$ and with a precision of $0.1 \mathrm{~kg}$. The automatic display was triggered by the touch of the feet when the machine was positioned on flat ground. Height was evaluated with a tape measure with a precision of $0.5 \mathrm{~cm}$, fixed to a smooth wall. Height measurements were taken with the students barefoot, with their backs to the wall, their feet together and parallel, standing straight and looking to the front. A ruler was placed across the tops of the participants' heads to ensure the accuracy of the measurement against the tape measure. The Body Mass Index (BMI) (individual's weight in kilos divided by the square of his or her height in meters) was calculated from these, and interpreted based on age and sex ${ }^{(14)}$. Waist circumference was obtained at the smallest circumference located between the ribs and the iliac crest, with a flexible non-stretch tape measure. The cut-off points followed specific recommendations for

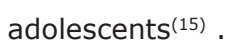

Data analysis was performed with the help of the SPSS software version 17.0. Average measurements, standard deviation and odds ratios, with their respective $\mathrm{CI}_{95 \%}$ were calculated. To ascertain the normality and homoscedasticity of the variables, the KolmogorovSmirnov and Levene's Tests were applied, respectively. For associations between variables, the $\chi^{2}$ test was used; the correlations were made with Pearson's correlation; the averages were compared using Snedecor's F-tests (if three or more in number), and Student's t test was used for independent data (if two groups). Analyses with $p<0.05$ were considered statistically significant.

The study was conducted with the approval of the Federal University of Piauís Committee for Ethics in Research, in accordance with protocol CAAE 0078.0.045.000-10. All participants had to present the terms of free and informed consent, signed by their respective parents or guardians.

\section{Results}

145 adolescents of both sexes were evaluated, of whom $62.7 \%$ were female. The participants were aged between 12 and 18 years old, with a mean age of 14.5 years. Concerning the family income of the subjects investigated, the results showed that in the majority of cases the adolescents lived in families with up to two minimum salaries per month $(84.1 \%)$. Concerning their educational level, approximately $75.2 \%$ of the students were studying at elementary level. 
It was ascertained, in a general way, that 13 $(9.0 \%)$ of the adolescents presented an elevated BMI, corresponding to being overweight [CI\% 73.0 - 86.0]. Elevations in WC were found in 31 (21.4\%) adolescents. Of the total number of subjects investigated, 76 (52.4\%) had elevations in AP pressure (Table 1).

Table 1 - Distribution of adolescent students, according to the risk factors for developing arterial hypertension investigated. Picos, Piauí, Brazil, 2010

\begin{tabular}{lccc}
\hline \multicolumn{1}{r}{ Risk Factors } & Num-ber & $\%$ & Cl $_{95 \%}$ \\
\hline BMI & 132 & 91.0 & $73.0-86.0$ \\
$\quad$ Normal & 13 & 9.0 & \\
$\quad$ Overweight & & & \\
WC & 114 & 78.6 & $73.0-86.0$ \\
$\quad$ Normal & 31 & 21.4 & \\
Elevated & & & \\
AP & 69 & 47.6 & $34.0-50.0$ \\
Normal & 56 & 38.6 & $27.0-42.0$ \\
Borderline & 20 & 13.8 & $8.0-18.0$ \\
$\quad$ Hypertension & & & \\
\hline
\end{tabular}

BMI: Body Mass Index; WC: Waist Circumference; AP: Arterial Pressure

In relation to the risk factors investigated for susceptibility for developing arterial hypertension, Table 2 shows the number of adolescents exposed to the risk of acquiring the disease according to each factor and its relation to sex. Following the classification of BMI, WC and $A P$, there was no statistically significant association for either $\operatorname{sex}(p=0.088 ; 0.999 ; 0.204$, respectively).

Table 2 - Characterization of Body Mass Index (BMI), Waist Circumference (WC) and Arterial Pressure levels (AP) and their relation with the sex of the adolescent students in the town of Picos, PI, Brazil, 2010

\begin{tabular}{|c|c|c|c|c|c|}
\hline \multirow{2}{*}{ Variables } & \multicolumn{2}{|c|}{ Male } & \multicolumn{2}{|c|}{ Female } & \multirow[t]{2}{*}{$p$} \\
\hline & $\mathbf{N}$ & $\%$ & $\mathbf{N}$ & $\%$ & \\
\hline \multicolumn{6}{|l|}{ BMI } \\
\hline Normal & 52 & 96.3 & 80 & 87.9 & $0.088^{*}$ \\
\hline Overweight & 02 & 3.7 & 11 & 12.1 & \\
\hline \multicolumn{6}{|l|}{ WC } \\
\hline Normal & 52 & 96.3 & 86 & 94.5 & $0.999^{\dagger}$ \\
\hline Elevated & 02 & 3.7 & 05 & 5.5 & \\
\hline \multicolumn{6}{|l|}{ AP } \\
\hline Normal & 22 & 40.7 & 47 & 51.6 & $0.434^{*}$ \\
\hline Borderline & 24 & 44.4 & 32 & 35.2 & \\
\hline Hypertension & 08 & 14.9 & 12 & 13.2 & \\
\hline
\end{tabular}

In relation to the number of risk factors presented by each adolescent, $37.2 \%$ had none of the factors investigated, showing that they were not exposed to the risk of developing $\mathrm{SAH}$. However, $44.8 \%$ of the adolescents had at least one factor; $15.9 \%$ had two, and $2.1 \%$ had three of the associated factors (Table 3 ).

Table 3 - Distribution of adolescent students, according to the frequency of risk factors for precocious Systemic Arterial Hypertension (SAH). Picos, PI, Brazil, 2010

\begin{tabular}{lcc}
\hline \multicolumn{1}{c}{ Number of Risk Factors } & N & $\%$ \\
\hline No factor & 54 & 37.2 \\
One factor & 65 & 44.8 \\
Two factors & 23 & 15.9 \\
Three factors & 03 & 2.1 \\
Total & 145 & 100 \\
\hline
\end{tabular}

The risk factors investigated are modifiable and knowing their frequency is important for planning individual and collective actions, based on principles of integrality and intersectionality.

\section{Discussion}

This work supplies data about the frequency of body mass index, blood pressure and the waist circumference and their association with the sex of adolescent students in the town of Picos, in Piauí, Brazil.

The prevalence of arterial hypertension has increased in the infant-juvenile population, varying from $2 \%$ to $13 \%{ }^{(16)}$. The present study identified $52.4 \%$ of the sample as having initial arterial pressure equal to or higher than the ninetieth percentile. Furthermore, another study ${ }^{(17)}$ identified a prevalence of the order of $7.7 \%$ among students aged 7 to 17 with arterial pressure equal to or higher than the ninety-fifth percentile, similar to the study carried out in the city of Fortaleza in the state of Ceará, where the prevalence of $52.4 \%$ was found.

In the present study however, it was noticed that females presented greater prevalencies both in the Body Mass Index (BMI) and the Waist Circumference, although without statistical significance. Analyzed, these data show a significant relationship with similar studies which indicate that increase in weight and the concentration of abdominal fat are strong indicators for the development of hypertension in adolescents of both sexes ${ }^{(7)}$.

Excess weight (overweightness, obesity) leads to abnormalities in arterial pressure and in the metabolism 
of lipids and glucose. The adverse impact of excessive weight on multiple cardiovascular risk factors calls for primary prevention at young ages, as, added to the evidence cited, studies indicate that excess weight in adolescence tends to persist into adulthood(19).

Brazilian studies ${ }^{(20-23)}$ show a variation of between $10 \%$ and $29 \%$ in the prevalence of excess weight. This study found $9 \%$ less excess weight than that found in Pelotas $^{(20)}$ in the state of Rio Grande do Sul, more than that found in Recife(21) in the state of Pernambuco, and similar to that found among adolescents in João Pessoa in the state of Paraíba(22) and Belo Horizonte in Minas Gerais $^{(23)}$.

It should be emphasized that considering WC, BMI and the levels of arterial pressure as risk factors for the development of arterial hypertension, $62.8 \%$ of the sample had one or more risk factors, which may lead to the appearance of SAH in adulthood in the future, or even in infancy ${ }^{(24)}$.

\section{Conclusion}

The results of the study indicated that $9.0 \%$ of the adolescents had elevated BMI. 21.4\% had an elevated WC and $52.4 \%$ had elevations in their AP, without any statistically significant difference between the sexes. However, the presence of one or more of these risk factors was present in $62.8 \%$ of the adolescents, which may leave them susceptible to the development of arterial hypertension and other chronic pathologies.

It is suggested, therefore, that intervention projects should be carried out in the town researched, via information and clarification, aimed at promoting healthier eating habits - principally in reducing the consumption of salt and fully-saturated fatty acids. The practice of physical activity should be stimulated through the expansion of spaces available and the implantation of programs for incentivizing adolescents to adopt a more physically-active lifestyle. It is suggested that the schools should develop an interdisciplinary pedagogical proposal which has health education in view. Individual and organizational changes can promote transformations in communities in general and, in this way, reduce the impact of cardiovascular diseases on this population.

The risk profile presented indicates the necessity for public policies aimed at combating risk factors for the development of arterial hypertension. Nursing, which already acts in school settings for educating in the prevention of sexually-transmitted diseases and drug abuse, among other tasks, can intervene effectively in this space, so as to carry out health education actions which favour the adoption of habits for healthy living.

Outside the school setting, the nurse can give this guidance as part of the Family Health Strategy, during consultations which form part of the Attention to Adolescent Health Program, during home visits and by means of campaigns in public places.

It should be emphasized that other risk factors could have been investigated, such as cholesterol levels, tobacco use and alcoholism, among others, which shapes the limitations of this study.

\section{References}

1. Miranzi SSC, Ferreira FS, Iwamoto HH, Pereira GA, Miranzi MAS. Qualidade de vida de indivíduos com diabetes mellitus e hipertensão acompanhados por uma equipe de saúde da família. Texto Contexto Enferm. 2008;17(4):672-9.

2. Ferreira JS, Aydos RD. Prevalência de Hipertensão Arterial em Adolescentes Obesos. Ciênc Saúde Coletiva. 2010;15(1):97-104.

3. Ministério da Saúde (BR). Hipertensão Arterial Sistêmica para o Sistema Único de Saúde. Brasília: Ministério da Saúde; 2006. 58 p.

4. Martins MCC, Ricarte IF, Rocha CHL, Martins RBMCC. Pressão Arterial, Excesso de Peso e Nível de Atividade Física em Estudantes de Universidade Pública. Arq Bras Cardiol. 2010;95(2):192-9.

5. Barreto Neto AC, Araújo EC, Silva KVP, Pontes LM. Prevalência de Hipertensão e Fatores Associados em Adolescentes Escolares no Sertão de Pernambuco. Rev Adolesc Saúde. 2010;7(4):22-9.

6. Mion D Júnior, coordenador. V Diretrizes Brasileira de Hipertensão Arterial. São Paulo: Sociedade Brasileira de Cardiologia; 2006

7. Guimarães ICB, Almeida AM, Santos AS, Barbosa DBV, Guimarães AC. Pressão Arterial: Efeito do Índice de Massa Corporal e da Circunferência Abdominal em Adolescentes. Arq Bras Cardiol. 2008;90(6):426-32.

8. Gomes BMRA, Alves JGB. Prevalência de hipertensão arterial e fatores associados em estudantes de Ensino Médio de escolas públicas da Região Metropolitana do Recife, Pernambuco, Brasil, 2006. Cad Saúde Pública. $2009 ; 25(2): 375-81$.

9. Oliveira AMA, Cerqueira EMM, Souza JS, Oliveira AC. Sobrepeso e obesidade infantil: influência de fatores biológicos e ambientais em Feira de Santana, BA. Arq Bras Endocrinol Metab. 2003;47(2):144-50. 
10. Cano MAT, Pereira CHC, Silva CCC, Pimenta JNM, Maranha PS. Estudo do estado nutricional de crianças na idade escolar na cidade de Franca-SP: uma introdução ao problema. Rev Eletrônica Enferm. 2005;7(2):179-84. 11. Barros VO, Silva ML, Gonçalves CC, Tavares JS, Silva ME, Guedes ATL, et al. Perfil alimentar de crianças com excesso de peso atendidas em unidades básicas de saúde da família em Campina Grande-PB. Alim Nutr. 2011;22(2):239-45.

12. National High Blood Pressure Education Program Working Group on Hypertension Control in Children and Adolescents. The fourth report on the diagnosis, evaluation, and treatment of high blood pressure in children and adolescents. Pediatrics. 2004;114(2 Suppl 4th Report):555-76.

13. Joint National Committee on Detection. Evalution and treatment of high blood pressure. The seventh report of the Joint National Commmittee on Prevention, Detection, Evalution and Treatment of High Blood Pressure (JNC VII). JAMA. 2003;289:2560-71.

14. Cole TJ, Bellizzi MC, Flegal KM, Dietz WH. Establishing a standard definition for child overweight and obesity worldwide: international survey. BMJ. 2000;320(7244):1240-3.

15. Taylor RW, Jones IE, Williams SM, Goulding A. Evaluation of waist circumference, waist-to-hip ratio, and the conicity index as screening tools for high trunk fat mass, as measured by dual-energy X-ray absorptiometry, in children aged 3-19. Am J Clin Nutr. 2000;72:490-5.

16. Sociedade Brasileira de Cardiologia. VI Diretrizes Brasileira de Hipertensão Arterial. Rev Bras Hipertens. 2010;13(1):1-68.

17. Silva MAM, Rivera IR, Ferraz MRMT, Pinheiro AJT, Alves SWS, Moura AA, et al. Prevalência de fatores de risco cardiovascular em crianças e adolescentes da rede de ensino da cidade de Maceió. Arq Bras Cardiol. 2005;84(5):387-92.

18. Araújo TL, Lopes MVO, Cavalcante TF, Guedes NG, Moreira RP, Chaves ES, et al. Análise de indicadores de risco para hipertensão arterial em crianças e adolescentes. Rev Esc Enferm USP. 2008;42(1):120-6.

19. Beck CC, Lopes AS, Giuliano ICB, Borgatto AF. Fatores de risco cardiovascular em adolescentes de município do sul do Brasil: prevalência e associações com variáveis sociodemográficas. Rev Bras Epidemiol. 2011;14(1):36-49.
20. Terres NG, Pinheiro RT, Horta BL, Pinheiro KAT, Horta

LL. Prevalência de fatores associados ao sobrepeso e à obesidade em adolescentes. Rev Saúde Pública. 2006;40:1-7.

21. Silva GAP, Balaban G, Motta, MEF. Prevalência de sobrepeso e obesidade em crianças e adolescentes de diferentes condições socioeconômicas. Rev Bras Saúde Matern Infant. 2005;5:53-9.

22. Farias JC Júnior, Silva KS. Sobrepeso/Obesidade em adolescentes escolares da cidade de João Pessoa - PB: prevalência e associação com fatores demográficos e socioeconômicos. Rev Bras Med Esporte. 2008;14:104-8. 23 Ribeiro RQC, Lotufo PA, Lamounier JA, Oliveira RG, Soares JF, Botter DA. Fatores adicionais de risco cardiovasculares associados ao excesso de peso em crianças e adolescentes. O estudo do coração de Belo Horizonte. Arq Bras Cardiol. 2006;86:408-1.

24 Macêdo SF, Araújo MFM, Marinho NPB, Lima ACS, Freitas RWF, Damasceno MMC. Fatores de risco para diabetes mellitus tipo 2 em crianças. Rev. Latino-Am. Enfermagem. [periódico na Internet] set-out 2010 [acesso 10 jan 2011]; 18(5): [08 telas]. Disponível em: http://www.scielo.br/pdf/rlae/v18n5/pt_14.pdf. 